\title{
The Norwegian Pentecostal Foreign Mission: A Survey of Mission History with an Emphasis on Organization, Expansion, and Gender
}

\section{Lisbeth Mikaelsson \\ WIN THE WORLD ${ }^{1}$}

In December 1906, the American strand of the Pentecostal revival was brought to Norway by Methodist pastor Thomas Ball Barratt (1862-1940). He returned from New York as a burning witness of rebirth in the Holy Spirit as it was preached and experienced in the Azusa Street milieu in Los Angeles, a milieu that had guided his own intense longing for the life-shaking event. Back in Kristiania (now Oslo), his evangelist fire immediately instigated a Pentecostal revival in the city. He soon caught the attention of Christian leaders from a variety of denominations in Scandinavia and other parts of Europe. Accepting invitations to preach at meetings abroad in 1907, Barratt toured countries in Europe, the Middle East, and India over the next few months. Thus the activities of Barratt himself, the progenitor of European Pentecostalism (Alvarsson 2011, 22; Bundy 2009, 174), demonstrated a

L. Mikaelsson $(\bowtie)$

University of Bergen, Bergen, Norway

(C) The Author(s) 2018

J. Moberg, J. Skjoldli (eds.), Charismatic Christianity in Finland, Norway, and Sweden, Palgrave Studies in New Religions and Alternative Spiritualities, https://doi.org/10.1007/978-3-319-69614-0_3 
missionary zeal combined with a world-oriented perspective-characteristics that have marked Pentecostalism through its history in Norway and elsewhere.

This chapter sketches Norwegian Pentecostal mission history from the beginning until the present. Within the format of a single chapter, that means a strict economy of topics will be needed. Since institutionalized arrangements in the home milieu are generally essential for the social and economic support most foreign missionaries need, a main issue here is the organization of Pentecostal foreign mission in Norway. In general, Protestant mission societies constitute common frameworks for the missionaries and their supporters at home. These frameworks influence options, strategies, and activities in the field as well as securing continuity of work. Thus, to a large extent, the adoption of the Christian faith in the Third World has been both directly and indirectly influenced by the missions' organizational structures. Among the many fellow-believers at home, an interest in mission and responsibility vis-à-vis the missionaries' circumstances has been promoted by the regular streams of information coming from periodicals and other literary productions issued by the organizations. Given Norwegian Pentecostals' emphasis on individual spiritual gifts and belief in the guidance of God, a key question here is to what extent they adopted the kind of multifunctional system typical of the Protestant missionary organizations. I am conscious that this approach means that central aspects of Pentecostal foreign mission are given less attention than deserved, and I try to make amends for it by presenting a few central cases in more detail. As in other branches of Protestant mission, women have numerically dominated Norwegian Pentecostal mission, and one of the aims of this chapter has been to shed some light on gender issues and the agency of women missionaries.

Constructing a "national" account of Pentecostal foreign mission is complicated by the decentralized character of this mission in Norway. Since the 1930s, mission has mainly been based in local congregations, or in some cases, independent foundations and even individual enterprises. This means that mission history largely consists of a bunch of locally anchored accounts yet to be investigated. Nevertheless, I try to impart a bird's-eye view to mission history, which remains greatly dependent on the following Pentecostal historical works: Oddvar Johansen et al.'s "Pentecostal Mission over 100 Years" (Pinsemisjon i $100 \mathrm{a} r, 2010$ ), Oddvar Nilsen's “Out into All the World: The Pentecostals' Foreign Mission in 75 Years" (Ut $i$ all verden: Pinsevennenes ytre misjon i 75 àr, 1984), and Martin Ski's “The Pentecostals' Foreign Mission" (Pinsevennenes Ytre Misjon, 1967). Additionally, the 
importance of the academic works of Nils Bloch-Hoell and David Bundy should be emphasized: Bloch-Hoell's The Pentecostal Movement: Its Origin, Development and Distinctive Character (1964) is a pioneering national and international contribution to research on Pentecostalism, which was generally ignored by scholars until the 1960s. ${ }^{2}$ Bundy's momentous Visions of Apostolic Mission: Scandinavian Pentecostal Mission to 1935 (2009) is a scholarly milestone in terms of the Scandinavian contribution to Pentecostal mission.

\section{The Initial Phase}

In 1909, Barratt emphasized the necessity of mission for "Pentecost friends" (pinsevenner) in his paper "The City Post" (Byposten) $)^{3}$ - the Norwegian name for Pentecostals here being used for the first time (Nilsen 1984, 25-26). Yet, Barratt himself represented the group of traveling evangelists, who in 1912 were criticized by E.N. Bell, editor of Word and Witness, ${ }^{4}$ for not staying with non-Christian peoples on a more permanent basis (McGee 2010, 120). However, Barratt was soon followed by Norwegian Pentecostals to the far ends of the earth, and several of them spent decades abroad. From early on in its history, foreign mission went hand in hand with the growing Pentecostal revival in Norway. In 1910 nine missionaries, five women and four men, set out to their chosen countries: India, China, Swaziland, and Argentina. By 1914, the number of missionaries had doubled (Gulbrandsen 1937, 135-136). The geographical dispersion demonstrates the aforementioned global horizon, as well as an individualist determination in the mental makeup of these pioneers. Their efforts were part of the wider Scandinavian Pentecostal missionary enterprise taking place in the first decades of the twentieth century. As argued by Bundy, Scandinavian activity has been vital for the development of global Pentecostalism, yet has been generally overlooked in scholarly studies outside Scandinavia (Bundy 2009, 1-3).

At the time, no coordinating institution in Norway existed that could influence candidates' decisions to become missionaries or where to go. Mission strategies and guidelines for the work were lacking in the new movement. Also, no arrangement securing a regular income for the missionaries had been established. In line with their own and their fellowbelievers' conviction, the pioneers trusted in the providence of God and the guidance of the Holy Spirit. They belonged to different groups and assemblies, and are considered Pentecostal because they had joined the revival and preached the gospel of rebirth and baptism in the Holy Spirit- not because 
they represented any established congregation (Nilsen 1984, 31). Many were "Free Friends" (Frie venner), an independent group associated with the Holiness movement. In its first years, the center of the Pentecostal revival in Kristiania was the Free Friends' assembly at Torvgaten 7, whose leader was Erik Andersen Nordquelle. He had welcomed Barratt and the Pentecostal revival, in contrast to the Methodist Church, which had turned against him (Bloch-Hoell 1964, 67-68; Bundy 2009, 177). The initial mission period of the Pentecostals and the Free Friends coincided, but subsequent developments would later create a schism between them, which will be discussed later.

\section{The Norwegian Mission Context}

Inspired by the Pietist movement, the Danish-Norwegian monarchy supported Lutheran mission in India, Greenland, and among the Sami peoples in the north of Norway during the eighteenth century (Danbolt 1947). A fundamental change took place in the nineteenth century, when foreign mission became a major interest for the rising lay movement and was no longer an elite activity controlled by state authorities. At the time when the Pentecostals appeared, the bulk of mission activities were directed by large lay organizations related to the Church of Norway and to some extent by alliance missions and the interdenominational China Inland Mission (CIM). A decisive move had been taken in 1842, when the Norwegian Missionary Society (NMS) was founded by a triune confederacy consisting of Moravians, ${ }^{5}$ clergy in the Lutheran state church, and lay people belonging to the revival instigated by evangelist Hans Nielsen Hauge (1771-1824). The Hauge movement had stayed within the state church, and the movement's vital role in religious, economic, and political developments in Norway is universally recognized (Aarflot 1969; Kullerud 1996; Molland 1979; Sjursen 1993 and 1997, II, III, IV). The foundation of NMS shaped the subsequent mission history of the country. This is due to the great impact of the Missionary Society itself; in addition, it functioned as a model for succeeding organizations affiliated with the Church of Norway. ${ }^{6}$ When the Pentecostal movement arose, there was already a nationwide mission culture rooted in the running of mission organizations. Madagascar, China, and India were well-known mission fields to domestic mission supporters. All the major organizations directed their efforts to selected mission fields that were agreed to by democratic decisions in boards and conferences. Money was collected in local mission 
associations through gifts and bazaars. Missionaries had salaries and could ask the central administration for extra grants for special needs or projects (Jørgensen 1992; Mikaelsson 2003; Seland 2001; Slettan 1992).

This kind of orderly mission system had demonstrated its viability for decades, but the Pentecostals questioned its spiritual character: Was the system too worldly, too powerful, too little guided by the Holy Spirit through spiritually equipped messengers? Yet, personal piety was not absent in contemporary mission, deeply rooted as it was in the lay movement and its pietistic religiosity. A subjective motivation, generally understood as a personal missionary calling, was inevitable. This represented the "inner call," while an organization's acceptance of a candidate was thought of as an "outer call." Together, they constituted a fulfillment of God's commission in Matthew 28: 18-20. The organizational apparatus invited every participant to understand herself as part of the god-willed project. Thus the mission call became a "democratic" idea and a vital ingredient in the common identity nourished by the organizations: this was the ideological basis of the social and economic alliance between missionaries abroad, administrative staff at home, and the large number of common supporters meeting regularly in thousands of local auxiliary associations. The missionaries filled the role of figures of identification throughout the entire system. Their first-hand stories from the field, about charity, education, and triumphant victories over "heathenism," were told in letters, reports, magazines, travelogues, and autobiographical accounts. These were generally published by the organizations or affiliated publishers for a domestic audience intent on learning how the work was going. It was supposed that the audience would appreciate stories confirming the positive effects of mission as well as its fulfillment of divine will. Descriptions of exotic scenery and strange customs often seasoned the accounts and made for good entertainment. No wonder mission supporters at the coming of Pentecostalism belonged to the most internationally oriented part of the Norwegian public (cf. Mikaelsson 2003).

Norwegian Pentecostals were not unaffected by contemporary mission culture and its legacy from the Hauge revival. Barratt and his followers admired Hauge and looked upon him as a spiritual model; Barratt even thought that Hauge had experienced a baptism in the Holy Spirit (Bundy $2009,34)$. Thus in Norway, Pentecostal self-understanding and theory of mission were not only inspired by Methodist and Holiness influences, but also by the Pietist legacy, as Bundy has argued (2009, 32-38). The conviction that other religions were "heathen" idolatry-widespread in Protestant mission-found continuity among the Pentecostals (cf. Anderson 2009). 
Parallel to the situation in other Norwegian missions, literary production and emphasis on literacy became part of Pentecostal foreign mission. The periodical "The Victory of the Cross" (Korsets Seier) was an arena for mission-related subjects from the outset. Besides, letters were welcomed in other periodicals and local papers, and missionaries published book-length accounts of their lives and experiences. ${ }^{7}$ If evangelism is the heart of Pentecostal mission, its biblical focus necessitates literacy. Thus alphabetization has been a major missionary task. The distribution of tracts, newsletters, and excerpts from the Bible has been a common working method. ${ }^{8}$ Written language and translations of the Bible in vernacular languages, however, have generally been present in places where Norwegian Pentecostals have worked (Nilsen 1984, 91). The corporate leadership model developed by the main Lutheran organizations was not embraced by the Pentecostals, and history demonstrates that finding pragmatic, institutional solutions to practical problems proved to be challenging. Nor did the Pentecostals establish obligatory education for prospective missionaries. Their educational background therefore varied. Bible courses, language courses, and missionary courses abroad prepared them for the task.

\section{Tension Between Spiritual Idealism and Practical Circumstances}

A premillennialist belief in the return of Christ affected the Pentecostal understanding of the mission call and fueled the urge to bring the gospel to the "heathen world" (cf. Anderson 2009; McGee 2010). Matthew 24: 14: "This gospel shall be preached to all nations and then the end shall come," guided the Pentecostals' understanding of mission (Dyer 2011, 11). Spirit baptism accompanied by glossolalia, as well as healing and prophecy, were classical Pentecostal elements that were passed on to Third World converts. The belief that xenolalia is a means to convey the gospel's message in the listeners' native languages has been cherished in Pentecostal circles; Barratt himself expressed such notions (Bloch-Hoell 1964, 87). Dagmar Engstrøm, a Norwegian pioneer credited for bringing Pentecostalism to Germany, declares that she was appointed by Barratt to take on this task because she had spoken German in tongues without knowing the language (Engstrøm $1980,23)$. The extreme idea that this gift is sufficient missionary equipment (cf. Anderson 2009, 121), making it unnecessary to learn foreign languages, 
does not seem to have had any significant support among Norwegian Pentecostals, however.

In any case, emphasis on the missionaries' individual calling and spirituality characterized Pentecostal foreign mission in Norway from the start. Initially, mission was primarily conceived as a relationship between the missionary and God. The individual was the immediate divine instrument, and did not need any social arrangements that could interfere with this relationship. These ideas were not unfamiliar among Free Church groups who were impacted by the Holiness movement or to supporters of interdenominational alliance missions. The Methodist missionary William Taylor's ideal of self-supporting missions was well known (Bundy 2009, 71-73), as was the "faith principle" of the China Inland Mission. The "faith principle of support" holds that the missionary should not ask for any support except in prayers to God, trusting Hudson Taylor's famous declaration: "God's work done in God's way will not lack God's supply" (Fiedler 1994, 28). Yet, fellow-believers at home were expected to sustain the missionaries with their voluntary gifts. Thus they might function as God's instruments and partakers in the mission. Sometimes their assistance was interpreted as divine intervention in acute situations of need or distress, as my research in Norwegian mission literature has documented (Mikaelsson 2003). Generally, accounts of this kind support the conviction, not restricted to Pentecostals, that economy is a sphere where divine providence is realized in a way that makes miracles happen, creating a narrative blend of excitement and edification.

Nevertheless, lack of stable means soon led to tangible problems for the missionaries abroad. The common link between missionaries and the Pentecostals at home was the periodical "The Victory of the Cross" (Korsets Seir). ${ }^{9}$ It printed accounts of gifts to the missionaries as well as letters and reports from them. Other papers publishing letters from the missionaries were "The Good News" (Det gode budskap), published by Nordquelle, and "The Missionary" (Missioneren), with Carl Magnus Seehuus as editor from 1914 (Bundy 2009, 316; Nilsen 1984, 32). Without a central institution to distribute resources, the missionaries' writing skills influenced the readers' willingness to supply their ministries with money. Yet, sporadic gifts from family, friends, and assemblies were often insufficient for catering to the missionaries' needs. Besides, the somewhat unpredictable character of the mission work itself sometimes created difficulties. This engendered tension between spiritual and practical considerations, which modified the individualized spiritual understanding of foreign mission. 
When the Pentecostal Missionary Union was established in England, Barratt was invited to its first general assembly in 1909. He returned full of enthusiasm, and proposed that a similar organization in Norway should be ventured. The reception among many followers was chilly, however, bespeaking a critical approach to mission agencies that was not infrequent in early Pentecostalism. The Assemblies of God, founded in 1914 in the United States, had to tackle similar sentiments (cf. McGee 2010, 120-121, 140). Barratt's followers supported foreign mission, but insisted that the Holy Spirit should lead the work, not a human device (Ski 1967, 452).

Eventually, a Pentecostal mission organization, "Norway's Free Evangelical Heathen Mission" (Norges Frie Evangeliske Hedningemisjon), was founded during the next few years. The opposition to it did not disappear, however, and its existence was over when Barratt himself joined the opponents. The idea that foreign mission should be anchored in local congregations has since been dominant among Norwegian Pentecostals.

\section{The Pioneers}

Pentecostal historiographer Oddvar Nilsen names five men and 10 women who became foreign missionaries during the period 1910-1913 (Nilsen 1984, 30-31). Four of these young women married foreign missionaries and disappeared out of sight, and one of the young men died in China in 1912. Among the rest were Henrik Engstrøm and his wife Dagmar, who founded the Banda mission in India; Parley Gulbrandsen and his wife Chrissie, who established mission in China, Gulbrandsen originally representing the Tsjili Mission run by "The Norwegian Missionary Alliance" (Den Norske Misjonsallianse); ${ }^{10}$ Laura Strand and Anna Østreng in Swaziland, where Strand founded the New Haven mission station; and in Argentina, Berger N. Johnsen, who started the Embarcación mission in the Salta Province there and took up a ministry among Indian tribes. Several of the pioneers were sustained economically by the Free Friends.

Dagmar Engstrøm (1882-1984), born Gregersen, occupies a special place in Norwegian Pentecostal history. She is recognized as the first foreign missionary along with Agnes Thelle (1876-1968), having been called to service in a way that has become part of Pentecostal lore. During a private prayer meeting in Kristiania, a woman is said to have prophetically proclaimed: "Dagmar, Dagmar, look, I will send you to the dark place of Banda,"11 a name the young Dagmar had never heard of, but accepted as the place she was destined by God to go to. It proved to be a district in 
Northern India with a population of about 1 million people (Engstrøm $1980,16)$. In the centenary publication "Pentecostal Mission over 100 years" (Pinsemisjon $i 100 \mathrm{ar}$ ), the first article, illustrated with a large photo, is devoted to Engstrøm's missionary calling and lifelong service of the movement (Johansen et al. 2010, 4-7). Her calling and her response to it provided the mission with what might be called a mythical beginning. ${ }^{12}$

Engstrøm was not just a pioneer in India. With her companion Agnes Thelle, she brought the Pentecostal movement to Germany and Switzerland during the summer of 1907. Representatives of the German Gemeinschaftbewegung, a counterpart to the Lutheran Inner Mission in Norway, were interested in the revival set in motion by Barratt, and the two women were invited to Germany by Emil Meyer, leader of Hamburg Strandmission, who had visited Kristiania and been impressed by what he had witnessed. Engstrøm and Thelle first went to Hamburg, and then to Kassel. In Kassel, their public meetings in the period July 7-August 2 resulted in commotion and negative reporting in the press. The reason for this was the ecstatic experiences and extraordinary bodily phenomena that had gradually turned the meetings into apparently chaotic occurrences. The revival, called Die Kasseler Bewegung, was strongly opposed by religious and secular authorities in the region; even the German empress denounced it (Bloch-Hoell 1964, 80; Bundy 2009, 204-206; Simpson 2011, 62-63). Evangelist Heinrich Dallmeyer, who had experienced baptism in the Spirit himself when participating in the Hamburg meetings, had invited Engstrøm and Thelle to Kassel. He conducted the meetings in the city, but did not succeed in maintaining control when the ecstatic manifestations were at their strongest. Later, he joined other men in the Gemeinschaftbewegung who repudiated the Pentecostal revival and warned against the Spirit mediated by the women. The series of meetings held by Engstrøm and Thelle at this time is nevertheless acknowledged as the start of Pentecostalism in Germany (Meyer 2015, 97-101). ${ }^{13}$ In her autobiography, Engstrøm presents her own version of these events. She applauds the fire that inflamed the meetings in Kassel, and regards the opposition as the work of Satan. Dallmeyer is dismissed as a traitor. According to Engstrøm, he had confided to her and Thelle that he abandoned the revival for fear of losing his wages if he left the Lutheran church (Engstrøm 1980, 25-34).

In 1908 the two women went to A.B. Simpson's Missionary Training Institute in New York. After finishing their education they traveled to 
India together in March 1910. Some months later, Dagmar married missionary Carl Henrik Engstrøm. Faithful to the geographical specification in her calling, the couple arrived in the city of Banda in 1911 with their newborn son. ${ }^{14}$ After her husband's early death in 1921, Dagmar continued in Banda on her own, with three children to provide for, until she finally left India and returned to Norway in 1943, during the Nazi occupation (Engstrøm 1980, 129).

Engstrøm's autobiography "Have Faith in God. All is Possible for the One Who Believes" (Ha tro til Gud. Alt er mulig for den som tror, 1980) was published when the author was nearly 100 years old, but the book is replete with lively memories. ${ }^{15}$ It portrays a character with never-wavering faith, and a life abounding with spiritual experiences. At the beginning of the twentieth century, deviations from central doctrines in the Lutheran state church involved social costs; thus the author had to leave her position as a schoolteacher after being rebaptized in 1907 (1980, 19). In her description, "the dark place Banda" turns out to suffer from social want and Hindu idolatry, true to the cliché of "heathen darkness." More surprisingly, the epithet is also used to characterize the colonial racism that forbade Indians to enter the local English church in Banda (1980, 70-71). In spite of the premillennialist insistence on the priority of evangelization before the coming of Christ, the need and suffering that Pentecostal missionaries encountered in the Third World resulted in the founding of schools, orphanages, clinics, and hospitals, as they did in other missions. Engstrøm specifies that one aspect of the darkness of Banda was the karma doctrine that induced parents to abandon those children supposedly born under an unlucky star. The misery of these little ones begging in the streets soon moved the Engstrøm couple to establish an orphanage in Banda. Here, banished widows were also allowed to settle. The children were taken care of by Indian Bible women and sent to schools when they grew older (Engstrøm 1980, 91-92). ${ }^{16}$

The international networking among Pentecostals in the first decades of the twentieth century is illustrated in Engstrøm's work. Like Barratt before them (Barratt 2011, 180), Dagmar Engstrøm and Agnes Thelle visited Pandita Ramabai's Mukti Mission for young widows and orphans near Pune. Ramabai (1858-1922) was an exceptional Indian woman: feminist, scholar, author, educator, and social reformer. The honorific title pandita ("learned") was given her in Calcutta in 1873 as an acknowledgement of her Sanskrit learning (Sugirtharajah 2005, 7610). In 1905, a Pentecostal-type revival burst forth at the Mukti Mission, and hundreds of 
young women brought the revival to villages in the district. This femaleled revival made the Mukti Mission a renowned Pentecostal center of international importance (Anderson 2015, 2). ${ }^{17}$ Engstrøm and Thelle spent about six months at the Mukti Mission, and Engstrøm paints an enthusiastic portrait of Ramabai, representing her as a woman who believed strongly in Christ, the Bible, and God's guidance, and distanced herself from the Hindu religion. Allegedly Ramabai was deeply impressed by the mission call to Banda that had induced Engstrøm to go to India (Engstrøm 1980, 51-54). There is no trace in Engstrøm's recital of the complex figure described in other's accounts of Ramabai, and whose religious commitment, according to Sharada Sugirtharajah (2005), is not easily categorized. Neither does Engstrøm report any feminist discussions taking place during their stay at Mukti. In fact, feminist considerations have hardly any place in Engstrøm's book, except for a brief passage about veiled women wearing the purdah (1980, 100-101), an example of a common stereotype of women's misery in "heathen" countries (cf. Mikaelsson 2005). The import of Engstrøm's silence should not be overestimated; rather, the account of her actions and career indicates a person identifying with ideals of gender equality.

\section{A Controversial Issue: How to Organize the Mission}

Voluntary gifts were an unstable means of support. Besides, the practice entailed unequal distribution of resources among colleagues in the same field. Since there was no external control of how the means were allocated, nor of the activities individuals chose to undertake, problems of various kinds often arose. The ideal of self-supporting mission turned out to be hard to put into practice. When the Engstrøm couple was home on furlough, steps were taken to procure an administrative institution in Norway to oversee and regulate the mission work in Banda. A committee called "The Banda Mission" (Bandamisjonen) was then officially established on January 1, 1914. Barratt accepted the office of chair, his wife Laura Barratt was secretary, and Edvard Gasman treasurer (Bundy 2009, 321). From then on, gifts to the Banda Mission would be sent to the treasurer, as opposed to directly to the missionaries. Candidates for missionary work were required to produce letters of recommendation from their congregations, so that possible "adventurers" could be eliminated. A medical certificate was required, as was proficiency in the English language. No expansion in the mission work in Banda should be undertaken without the committee's permission (Bundy 2009, 321; Nilsen 1984, 33). Thus the Banda mission was organized with 
a set of directives that sorted out the candidates, regulated activities in the mission field, controlled its economy, and handed over the power of making vital decisions to a home administration.

Barratt and missionaries in other fields realized that the existence of some organizational structures could facilitate the work of their ministries. At a large meeting in 1914 hosted by "The Tabernacle" (Tabernaklet) in Skien, Telemark, Barratt suggested that the Pentecostals should develop "a more joint form of mission activity in Norway" (Nilsen 1984, 34). He was supported by the pastor of The Tabernacle, Carl Magnus Seehuus ${ }^{18}$ and others, and on January 30, 1915, the organization "Norway's Free Evangelical Heathen Mission" (Norges Frie Evangeliske Hedningemisjon; NFEH $)^{19}$ was founded. The statutes laid down that NFEH was open to every Pentecostal congregation or assembly that wanted to join it, whether in Norway or in the mission fields. Every such unit had the right to be represented at the annual meeting of NFEH by its pastor or another appointed person. To take care of the associated work, a mission council with a chairman, treasurer, and secretary would be elected/re-elected at the annual meeting. The council was NFEH's executive body and had the power to make vital decisions concerning the mission work and the establishment or expansion of mission stations, as well as the acceptance and dispatch of missionaries. Several statutes give instructions to control the use of economic resources, which was seen by some as an encroachment on the spiritual freedom many valued so highly. Receipts of money were to be published in "The Victory of the Cross" or "The Missionary"; both publications had reader networks that supported the mission economically. Yet, donors could still decide which mission would receive their gifts. Barratt was elected chairman of the council, and his wife became secretary. She was one of two women in the first council. A corresponding administrative unit, that is, a missionary council with chairman, treasurer, and secretary, was to be established in every country in which NFEH missionaries worked. One of the council's tasks was to draw up a budget plan for the following year, but to be valid the budget had to be accepted by the NFEH council in Norway (Nilsen 1984, 40-42).

More cooperation, and more control of personnel and resources within a formalized leadership structure based on a democratic foundation made the NFEH more bureaucratic and less "spiritual," in other words more like other mission agencies at the time. Not unexpectedly, the establishment of what was understood as a haunting by the "ghost of organization" (Nilsen 1984, 45) was met with mixed feelings in the Pentecostal milieu. Berger 
Johnsen in Argentina was one of those missionaries who worked all his life without any congregation backing or substantial economic support (Iversen 1946, 12). He seems to have had closer connections with the Free Friends than with the Pentecostals associated with Barratt and the "Victory of the Cross" network (Bundy 2009, 348). The Banda Mission had served as a model for NFEH, but to the disappointment of Barratt and others the Engstrøms chose not to join the new organization; thus the Banda Mission committee continued as before. Dagmar Engstrøm just hints at the founding of NFEH in her autobiography. At the time, she had decided that her faith in God should be her only support, she says, confirming her stance with a miracle story of the Lord supplying the mission station with money at a critical moment (Engstrøm 1980, 102-105). Bundy indicates that the Banda Mission and the Bilaspur Mission of Agnes Thelle Beckdahl refused to join NFEH because they had lucrative contacts with congregations in the United States that they did not want to be published in "The Victory of the Cross" or "The Missionary." However, the respected missionaries Gunnerius Tollefsen (Congo) and Parley Gulbrandsen (China) gave the new organization credibility by instantly joining it (Bundy 2009, 327-328).

Nonetheless, many Free Friends, including Nordquelle, were hostile towards NFEH (Froholt 1997, 3). Barratt's subsequent congregation policy further estranged him from this group, which denounced denominations and formalized congregations as 'unbiblical' and an origin of divisions between believers. In 1910, while still a member of the Methodist church, Barratt had founded an alliance assembly at Møllergaten 38 in Kristiania. In 1916 he instituted a congregational order at "Møllergaten 38," as the assembly was popularly called until it was named Filadelfia in 1921. In accordance with his vision of New Testament congregations, the Kristiania congregation should be independent and self-governed, have a pastor and a board of elders, thus realizing his understanding of the "biblical" model. Further, members should be accepted and registered, an unacceptable measure in the eyes of many Free Friends (Froholt 1997, 1). The same independent and formalized congregation structure was to be implemented in the mission fields. As a consequence of his founding this establishment, Barratt left the Methodist Church in $1916 .{ }^{20}$ Subsequent history shows that the Filadelfia model was copied around the country and inaugurated "the era of local congregations" in Norwegian Pentecostalism. In the period 1917-1933, 130 local Pentecostal congregations were registered (Ski 1967, 457-460). ${ }^{21}$ Many of these were originally Free Friends assemblies, and the organizing process often entailed bitterness and division between the followers of 
Barratt's line and the others, who remained Free Friends. As time went by, the last-mentioned group established their own organization, "The Free Evangelical Congregations" (De Frie Evangeliske Forsamlinger).

The congregation model was fundamental to the future organization of foreign mission, and it contributed to the closing down of NFEH. It turned out that the emphasis on the independent status of each congregation was difficult to reconcile with the superior authority of the NFEH council, in spite of the organization's relative success, having as it did, 30 missionaries in the mission fields in 1929 (Barratt 2011, 216; Nilsen 1984, $60) .{ }^{22}$ By this time Barratt had started to question the legitimacy of the organization. He decided that a mission board with the power to control the congregations' activities and resources, be it home mission or foreign mission, was unbiblical (Barratt 2011, 233). Consequently, he and his wife withdrew from the NFEH in 1930. His actions did not gain universal support at the time, and a critical period for Norwegian Pentecostalism followed (cf. Bundy 2009, 437-445). Yet, Barratt's authority was such that NFEH's fate was sealed. In 1931 the organization was closed down except for its work with the Congo mission, which was retained because the Belgian authorities in Congo demanded there be a legal entity behind the mission (Nilsen 1984, 60-64; Ski 1967a, 462).

Henceforth, local congregations took responsibility for the support of one or more missionaries. "The Victory of the Cross," which was published by the Filadelfia congregation in Oslo, became the mission's communications organ, and here mission reports and receipts for money transactions would be published. The development in Norway paralleled events taking place in Sweden, where Lewi Pethrus was instrumental in the closing down of the "Swedish Free Mission" (Svenska fria missionen) in 1929, which had been established five years earlier (Alvarsson 2011, 28). Barratt and Pethrus were close, and Barratt was probably influenced by the events in Sweden (Ski 1967, 460). Initially the rearrangement caused a variety of problems, but gradually the mission work stabilized in accordance with the new circumstances.

\section{Development of a Lasting Organizational Structure}

The 1930s were marked by a rapid Pentecostal growth both domestically and in the mission fields. When the Second World War broke out in 1939, the number of Norwegian missionaries had grown from 30 to 75 . The number shrank to 60 missionaries during the war, but in 1945 more 
than 100 people were ready to depart for the mission fields (Johansen et al. 2010, 20; Nilsen 1984, 79). The expansion was welcomed, but difficult to handle for the congregations. No one had a general overview of the situation, and a need for administrative assistance and cooperation was felt. Thus the fear of a central organization that would affect the independence of the congregations, a fear that was still existent in many quarters, was surmounted by acute need.

The first step was to establish the position of mission secretary in the Filadelfia congregation in Oslo in 1946. The reputable Congo missionary Gunnerius Tollefsen (1888-1966) was appointed to the job. ${ }^{23} \mathrm{He}$ was to serve all Pentecostal congregations and groups in Norway who needed his assistance; the secretary therefore had a key role on a national level. The next stage was the emergence of conferences related to the different mission fields, such as the South America conference and the East Africa conference. They functioned as meeting places for missionaries and representatives of the cooperating congregations supporting them. The field conferences and their respective working committees were officially accepted at a national Pentecostal conference in Oslo in 1949. Common funds were allotted to each field, and missionary salaries, travel regulations, and other practical affairs were handled within this framework (Nilsen 1984, 81-82; Ski 1967a, 467-470).

The organizational structure comprising mission secretary, field conferences, and working committees was thought to combine congregational and administrative interests. With adjustments and personnel growth this model has survived to the present. The field committees were closed down in 2008 and replaced with mission country committees (Johansen et al. $2010,104)$. The secretary has been promoted to general secretary, and is now assisted by a staff of eight employees, plus volunteers. Presently, the mission fields are apportioned to four main regions, Africa, America, Asia, and Europe, each with a regional secretary subordinated to the general secretary. The acronym PYM, short for De norske pinsemenigheters ytremisjon ("The Norwegian Pentecostal Congregations' Outer Mission"), ${ }^{24}$ is generally used to refer to the organization. It is defined as a "nonprofit association" in the statutes, and functions as a coordinating office for the mission work run by affiliated congregations. ${ }^{25}$ Well-informed readers will be familiar with the sometimes confusing use of "PYM" in Pentecostal texts: On the one hand, PYM, or its full name, may refer to the missionary activities that have been going on since 1910; in other words it is not a formal name but a denotation. On the other, PYM may be used as the name of the organizational structure that has developed since 1946. Even more confusingly, 
PYM may be used to refer to both, perhaps signifying the lasting influence of anti-organizationism. The congregations still function as employers and take responsibility for sending out missionaries, thus preserving the independent, decentralized structure that has been so strongly emphasized in the above history. For now, PYM does not have a complete overview of Pentecostal mission activities. There are independent missionaries and mission foundations, some of which are private, while others are attached to local congregations (PYM 2015). ${ }^{26}$ Thus Pentecostal foreign mission in Norway takes the form of a rather fragmented and complex conglomerate.

\section{Summary of the Missionary Expansion}

Looking at the number of missionaries, mission countries, stations, and activities from 1910 onwards, the word "expansion" can be said to sum up missionary development during this period. This growth has made PYM the third largest mission agency in Norway, with the widest geographical range. Today, PYM missionaries work in 30 different countries. In addition, PYM has partnerships with 19 more countries, and missionary activities in a number of countries details of which are kept secret for security reasons. Yet, the decrease in missionary activities that has taken place in Norway more generally has also befallen the classical Pentecostalism represented by PYM and its 293 affiliated congregations. As of 2015, the number of active missionaries who were sent from Norway is 94, including 24 retired missionaries who still work abroad or commute. This is a marked decline compared with earlier periods. It is necessary to take into account the broader picture, however. Partnerships with national Pentecostal churches have become a common mode for work, and Norwegian missionaries have to a great extent been substituted by local evangelists. The global diffusion of Pentecostalism makes financial support of homegrown projects and collaborators in many cases a preferable use of Norwegian resources. Today, the PYM leadership estimates that 300 million NOK (Norwegian crowns) are spent on mission purposes abroad. ${ }^{27}$

Until the Second World War, growth was concentrated in the original mission countries, India, China, Swaziland, and Argentina, supplemented with Congo, Iceland, ${ }^{28}$ and Brazil. In Brazil, Ragna and Leonard Pettersen began their work as representatives of the Arvika congregation in Sweden, but they had additional support from various Norwegian congregations. In 1936, Paraguay received its first Norwegian missionary (Nilsen 1984, 75-76). In 1946, it was settled that Israel would become a mission country, 
and in the same year Thailand and the Faeroe Islands received their first Pentecostal missionaries from Norway. In 1947, Chile, Tibet, and Kenya were added. Also, three missionaries went to South Africa that year (Nilsen 1984, 88-89). The expansion continued into the 1950s, when missions were opened in Japan, Morocco, Bolivia, Basutoland, Taiwan, Nepal, and the West Indies. Further expansion took place in the 1960s, adding Tanzania, Mozambique, Peru, Pakistan, Myanmar, and Greenland to the list. From the 1970s onwards, activities were started in Honduras, Madeira, Somalia, Niger, the Philippines, and Rwanda. In addition, the 1970s saw a greater focus on Europe (Nilsen 1984, 132-133). The year 1980 seems to represent the heyday of the Norwegian Pentecostal mission; on its seventieth anniversary celebration this year, it was reported that 350 missionaries were working in 30 different countries (Johansen et al. 2010, 76). Statistics published in 2010 demonstrates that 40,4 percent of a total of about 1000 missionaries has worked in Africa, 24,6 percent in Latin America, 22,2 percent in Asia, and 12,8 percent in Europe (Johansen et al. 2010, 108). Both efforts and results vary when comparing the countries. This variation can be partly explained by the Pentecostal respect for the individual missionary vocation and its specific geographical assignment. Moreover, the large variety of countries would hardly have been probable given a more corporate and less spiritual apparatus to handle the choice of mission fields.

Before the Communist Revolution, the greatest progress had taken place in China. Parley and Chrissie Gulbrandsen had attended the inaugural meeting of NFEH in May 1915, and afterwards prepared to return to China under its aegis. Back in China in 1916, they settled in Sin-Pao-an in Chih-li Province and made it the center of their activities. The Gulbrandsens established a partnership with the capable Chinese Pentecostal David Li, and their successful ministry resulted in new congregations in nearby cities and towns under the leadership of Chinese pastors (Bundy 2009, 339). At the turn of the year 1936/37, there were eight main mission stations with many affiliated minor stations and Sunday schools. When the Communist revolution prohibited all Christian missions in 1949, it has been estimated that a total of more than 40 missionaries operated in the country and more than 1000 members of the congregations were left behind (Rudolf and Jones 1967, 483-484, see also Bundy 2009, 3). After the revolution a number of the missionaries went to Japan. Here, seven mission stations were operational in $1952 .{ }^{29}$ In contrast to troubled China, with its crowds of refugees and robber gangs, civilized Japan proved to be a stubborn mission field. The scarce number of converts here has invited the 
metaphor of fishing with a fishing rod (Nilsen 1984, 98-99), as opposed to the "fishing net" success in Congo, where multitudes were "captured."

The Congo mission is considered the most successful of the Norwegian Pentecostals' missions. It goes back to 1915, when Gunnerius Tollefsen went to Congo, not under the aegis of NFEH, but of the Congo Inland Mission. This mission was founded in 1911 by the Pentecostalist Alma Doering from Ohio, backed by American Holiness Mennonites. Scandinavian Pentecostals viewed Doering's as a partner mission; however, cooperation with the Americans turned out to be frustrating for the European missionaries (Bundy 2009, 329-330). When Tollefsen returned to Norway in 1919, he advocated greater commitment among Norwegian Pentecostals for mission in Congo, and was supported by Barratt. Lewi Pethrus and other Swedish Pentecostals were also interested in opening a mission in the country. Thus an expedition led by Tollefsen on behalf of Norwegian and Swedish Pentecostals departed for eastern Congo in 1921 in order to find a suitable field. In 1922 the expedition settled in Nya Kaziba in the Kivu Province in Belgian Congo (Zaire). Here they started a ministry in cooperation with tribal leaders (Bundy 2009, 334-335). Nya Kaziba, with neighboring kingdoms Nya Luindja and Muganga, became the Norwegian field (Ski 1967a, 496-499). As early as 1923, the missionaries reported a revival comprising several hundred converts (Nilsen 1984, 50-51). In 1925, Tollefsen published "In the Interior of Africa. Experiences and Impressions from an Expedition Journey" (I Afrikas indre. Oplevelser og inntrykk fra en ekspedisjonsreise), a book describing the expedition and the first years of the work in Congo, also demonstrating the disastrous effects of European colonial exploitation in this part of Africa. The book has been characterized as "the first Pentecostal book-length missiological analysis of a particular mission field" (Bundy 2009, 336).

After 25 years of work, there had been significant growth in all respects: the mission staff now numbered 26 missionaries and between 70 and 80 Congolese assistants, five major mission stations and 40 affiliated minor stations were in use, between 3000 and 4000 children attended the schools, and 1000 people had been baptized (Nilsen 1984, 83). Ten years later, the number of baptized Congolese had increased to 6205. A hospital in Nya Kaziba was finished in 1958, and a Bible school started in 1956 at the mission station Muganga. Furthermore, it was reported in 1952 that 17,000 copies of Barratt's booklet "Clues in the Word of God" (Ledetraid $i$ Guds ord, 1936) translated into Swahili, had been sold (Nilsen 1984, 95). The Republic of the Congo gained its independence in 1960, and the changing 
times were reflected in a decision by the field conference that year: henceforth the mission work would be directed by a council consisting of missionaries alongside Congolese pastors and elders. The placing of Congolese people in new leadership positions on equal terms with the missionaries was historic (Nilsen 1984, 93-96). However, political turbulence following in the wake of national independence worsened working conditions for the missionaries. As a result, in 1967 all of them had returned to Norway. The interruption proved to be short, and progress continued in spite of political unrest. In 1979, the "Norwegian" field encompassed 47 congregations, with a total of 37,559 members, while 9586 candidates were preparing for baptism (Nilsen 1984, 126).

In 1995, the national church Communauté des Eglises Libres de Pentecôte en Afrique (CELPA) was established. The Congo mission then transferred its work to that church. With the financial assistance of Norwegian authorities, specifically the Norwegian Agency for Development Cooperation (NORAD), CELPA has been able to develop an extensive network of schools and health institutions in parts of Congo. Presently, CELPA consists of 650 congregations with 300,000 members. It is a mission church with ministries in several African countries (Johansen et al. 2010, 95).

It has been maintained that the success of the long-lasting revival in Congo surpasses that of every other revival occasioned by Norwegian Pentecostal missionaries. A possible competitor might be the notable revival that took place at Gran Chaco in the 1930s, after Berger Johnsen (1888-1945) had invested 20 years of strenuous work with little result in Argentina. When he came to the Salta Province in 1914, the Indians were so hostile towards white people that it was dangerous to approach the places where they lived. Johnsen never gave up on gaining their confidence, however, and little by little he succeeded. According to his description, the revival suddenly started when he was speaking at a large meeting at which the crowd ecstatically experienced the presence of the Holy Spirit. From then on "the fire" spread among the Indians (Iversen 1946, 6-7; Johansen et al. 2010, 12-13; Nilsen 1984, 75).

\section{The Evidence of Faith World Evangelism}

A remarkable mission agency in Norwegian Pentecostalism is the independent foundation The Evidence of Faith World Evangelism (Troens Bevis Verdens Evangelisering). Its center, the "Valley of Saron" (Sarons Dal), was established in 1965. It is situated in the valley of Kvinesdal, in Vest-Agder 
county, southern Norway. The founder, Aril Edvardsen (1938-2008), was a renowned evangelist and one of the most innovative Christian leaders in Norway in his lifetime. Edvardsen's financial success, ecumenical profile, and openness towards the Charismatic Movement resulted in a long-lasting conflict between the Valley of Saron and central Pentecostal leaders (Alvarsson 2015, 49). ${ }^{30}$ His mission strategy was to support local Evangelists in their native countries instead of sending missionaries from Norway; thus Edvardsen was a forerunner to a development that was common in the mission in later years, exemplified here by the Congo mission described above. Nor did he create a mission organization; summer rallies and money collections through his magazine "Evidence of Faith" (Troens Bevis) secured moral and financial support for Edvardsen's projects. Hundreds of Evangelists connected to local churches were funded in this way.

Since 1970, the summer rallies in the Valley of Saron have annually attracted thousands of participants. Since the 1960s, many countries, notably in Eastern Europe, have been visited by Edvardsen's meeting campaigns. From the 1990s onwards, the campaigns focused on the Muslim world, where Edvardsen established contacts with political authorities-a strategy that was criticized by fellow Christians in Norway. In addition, Edvardsen was a pioneer in mass media mission, with his radio and television programs being broadcast in many countries. Since 1997, these have been distributed by a satellite broadcaster covering the Middle East, parts of Africa, and Asia. Today, Edvardsen's son Rune Edvardsen is the leader of the Valley of Saron (Rimehaug 2010).

\section{A Woman-Dominated Mission?}

The foregrounding of Dagmar Engstrøm in the Norwegian Pentecostal Movement's centenary publication may well be interpreted as a tribute to all the "sisters" that have served the mission. "Pentecostal Mission over 100 Years" demonstrates the preponderance of women. A list included in the publication, containing the names of about 1000 people who have been engaged in foreign mission for longer or shorter periods, documents this fact (Johansen et al. 2010, 108-112). The gender distribution is neither specified nor commented on in the document, but my counting shows that about 620 of the people enlisted are or were women. ${ }^{31}$ Aside from this numerical preponderance, it would be extravagant to consider the mission as woman-dominated. For one thing, all the mission secretaries so far have been male. Most of the well-known missionaries are men. 
Yet, without these women's engagement the mission would not have developed into the important force it has proven to be. Since gender relations in the movement have not been studied in depth, a few cases will be mentioned here that indicate the multifaceted nature of the gender issue; these examples are on a global scale and occurred within a 100-year period, and vary according to time, place, the individuals involved as well as the local conditions.

Barratt's attitude was probably a decisive factor in the first decades. Dagmar Engstrøm and Agnes Thelle belonged to Barratt's following in Kristiania; their pioneering missionizing in Europe had his sympathy and support. The fact that Laura Barratt and another woman were members of the NFEH Mission Council bespeaks an open attitude to women's roles on his part. In fact, Barratt was an outspoken critic of religious and worldly patriarchy. In "The Victory of the Cross" he supported women's ministries and their right to preach (Bundy 2009, 417-418). His views are expressed in the booklet "Woman's Position in the Congregation" (Kvinnens stilling $i$ menigheten, 1933). Using the New Testament, especially the Pauline letters, as an authoritative guide, Barratt argues that the apostle was the founder of women's emancipation (Barratt 1933, 7). He ascertains that women's qualifications enable them to perform all kinds of tasks in society and, called by the Holy Spirit, women are ready to fill every congregational role (Barratt 1933, 31-33).

Judging from later debates on these issues (cf. Hoaas and Tegnander 1984), Barratt's standpoint was much more radical than his successors'. This is argued in a recent study, which documents that attitudes are changing (Gunnestad 2015). According to the general secretary of PYM, today there are no formal rules preventing women's taking leadership positions. ${ }^{32}$ Still, a recent debate in the Christian daily "Our Country" (Vart Land) indicates that a number of Pentecostal women experience a male culture that impedes their seeking leadership positions and taking up preaching (cf. Aalborg 2014; Arntsen 2015; Myklebust 2014).

In the mission field, however, women have been able to preach and exercise leadership. Perhaps the most illustrious example of this tendency is Liv Haug (born 1943), a highly decorated Pentecostal missionary in the Peruvian Perené district in the Amazon jungle. Combining mission with entrepreneurial skills, Haug was elected chairman in Villa Perené (1982-1983), and Province Governor in the Perené region (1996-2002); both commissions reveal the high regard in which she is held by the local population. She arrived in Peru in 1971, and in 1973 she founded the congregation Iglesia Evangélica Filadelfia in Villa Perené, the province capital. The congregation, with 350 active members in 2010, is the basis for a large number of activities 
and projects. Sunday schools, Bible lessons, leader training, and radio broadcasting are all activities anchored in the congregation. More than 3000 women have been helped through the project "Women in Progress" (Kvinner i fremgang), and a sponsor system takes care of the poorest children. Starting with a bridge over Rio Perené, Haug has initiated a great number of building projects to improve the living conditions of the local population (Johansen et al. 2010, 38; Tveit 2011).

However, mission literature indicates a complex picture as to gender. Haug and a large number of devoted women remained single, thus enabling them to devote all their energy to the ministry. Berly Aarre Solvoll's "In the Hand of the Master" (I mesterens haind, 1983) testifies that Pentecostal women trying to combine ministry and married life may face problems. The author claims that she was called and guided by God to become a missionary, but after marrying the well-known missionary Arnulf Solvoll, he seems to have controlled her life. Seven children (three of whom died in the mission field) made it necessary for her to concentrate on household tasks. The couple seemingly disagreed about priorities; he uncompromisingly gave preference to his own missionary concerns, while she emphasized the children's needs. After having twice submitted to his demands that the family should go on furlough, she refused to return to Japan with him after the furlough had ended because of the disruption this would cause to the children's schooling. Interestingly, the decision is described in terms of a divine intervention. In despair over how to manage on her own in Norway with the children, she was comforted by God with the declaration "Your creator is your husband"33 (Solvoll 1983, 148). Solvoll became convinced that, in addition to supporting her revolt in this way, God had called her to take on children's work at home (1983, 146). When her husband returned, she was not prepared to accept him as head of the family any longer $(1983,153)$.

Presumably, Solvoll's submission is representative of many couples in the past, but her frank account of revolt and its spiritual legitimation is unusual in Norwegian mission literature. The social context at the time of publication gives a key to its frankness: The 1970s was a decade of feministinspired gender transformation in Norway, and by the 1980s the lives of missionary children had surfaced as a contested issue in the public sphere (Mikaelsson 2003, 184-185, see also Drønen and Skjortnes 2010). Solvoll's spiritual view of the situation indicates how empowering a subjective experience of divine support may be for a woman defying conventional gender norms. 
A general comment on the above exposition is that Norwegian Pentecostal mission exhibits Protestant women's thrust towards equality and authority when they are confident that their ministries represent the will of God-all the more convincingly if God has communicated it directly to them. A second condition is a social and religious framework that accepts, or at least does not undermine, women's aspirations (cf. Fiedler 1994; Okkenhaug 2003).

\section{Final Comments}

Today, Pentecostalism is a dynamic religious current operating on a global scale, and since its earliest days Norwegians have contributed to its growth. Thomas Ball Barratt was an important harbinger of the Pentecostal message to Europe; his enthusiasm moved a number of young Norwegians to go abroad with the same message. The Norwegian Pentecostal mission grew into a significant agency that has affected religion and living conditions in a great number of countries, and still does. The question of how to organize a foreign mission has proven to be a contested spiritual issue and has not been solved once and for all. The mission as a whole is characterized by decentralization, which distinguishes it from most other mission agencies in Norway. Women have dominated numerically, but men have generally taken the leadership positions. Yet, women have been able to do "men's work" in the mission fields, holding positions of authority and leadership there that have not been open to them in Norway.

Acknowledgment I would like to thank the general secretary of PYM, Bjørn Bjørnø, for his obligingness in answering my questions and providing me with information.

\section{Notes}

1. The heading refers to a Pentecostal traveling mission exhibition "Win the World" (Vinn Verden) in 1965. On board the ship, M/S Sailing Fair, the exhibition visited large parts of the Norwegian coast (Nilsen 1984, 121).

2. The book is a translated and revised edition of Bloch-Hoell's doctorate thesis: Pinsebevegelsen: En undersøkelse av. pinsebevegelsens tilblivelse, utvikling og serpreg med sorlig henblikk på bevegelsens utforming $i$ Norge (1956).

3. The paper was established in 1904, after Barratt had founded the interdenominational society "Kristiania City Mission" (Kristiania Bymisjon) in 1902. "The City Mail" (Byposten), renamed "The Victory of the Cross" (Korsets Seir) in 1909 was the first European Pentecostal periodical (Bundy 2009, 17). Later, the spelling changed to Korsets Seier. 
4. Word and Witness was originally an American periodical of the Church of God in Christ related to Charles Parham's Apostolic Faith Movement. In 1914, it became an official periodical of the Assemblies of God.

5. "Moravians" is the English name of a branch of the Pietist movement. It originated in Sachsen, Germany, where Count Zinzendorf established a place of refuge, Herrnhut, for Protestant dissidents in 1722. The Moravian revival (Brødremenigheten) reached Norway in the 1730s. By the year 1800 Moravian groups existed in a number of Norwegian cities, but the movement was practically extinguished by the 1880s, according to church historian Einar Molland. The Moravians were keen supporters of foreign mission (Molland 1979, 98-105; Øverland 1987).

6. Cf. "the Santal Mission" (Santalmisjonen), founded in 1867, and "the Norwegian Lutheran Mission" (Norsk Luthersk Misjonssamband), founded in 1891 .

7. The most prolific Pentecostal writer was Robert Bergsaker (1914-2009), who had a notable missionary career in India and Nepal. An obituary states that Bergsaker published 23 books besides newspaper and magazine articles (Bjøro 2009).

8. As a response to the lack of suitable reading matter in the local languages, “The Pentecostals's Literature Mission” (Pinsevennenes Litteraturmisjon) was established in 1950. The Pentecostal publishing company Filadelfiaforlaget undertook the task of providing books and papers (Nilsen 1984, 90).

9. The periodical was published in Swedish, Finnish, Spanish, and Russian editions (Bundy 2009, 18). As mentioned earlier, the spelling later became Korsets Seier.

10. The first Norwegian Pentecostal missionaries in China seem to have been Magna and Bernt Berntsen. According to Allan Anderson, the couple had experienced Spirit baptism on Azusa Street in 1907, and went to China in 1908 with a team of 13 missionaries to settle in Zhengding, 200 miles southeast of Beijing. In 1914 the Berntsens founded the Chinese periodical Popular Gospel Truth, connected with a church called Faith Union (Anderson 2009, 122-123).

11. In Norwegian: "Dagmar, Dagmar, se jeg sender deg. til det mørke sted Banda." Banda is situated 600 kilometres southeast of New Delhi in the Uttar Pradesh region.

12. The story is also told in Oddvar Nilsen's history (Nilsen 1984, 28-29).

13. In recognition of her status as the first person to proclaim the Pentecostal gospel in Germany, Engstrøm was invited as an honorable guest and speaker to a large Pentecostal anniversary congress in Hamburg in 1977 (Engstrøm 1980, 143).

14. Agnes Thelle established her own mission in Bilaspur near the Nepalese border. In 1915 she married Danish missionary Christian Beckdahl (Bundy 2009, 323; Nilsen 1984, 30). 
15. Readers of the book are not informed whether Engstrøm had written diaries, letters, or published articles about her work which might have helped her memory.

16. "Biblewomen" is a term for a native female mission worker and collaborator. Biblewomen would contribute to evangelization and offer various kinds of assistance.

17. Anderson mentions the Mukti Mission's impact on Latin American Pentecostalism, particularly in Chile. This was due to the intervention of Minnie Abrams, Ramabai's right-hand assistant. Abrams wrote a booklet, The Baptism of the Holy Ghost and Fire (1906), which inspired Methodist churches in Valparaiso and Santiago to pray for a similar revival. This revival actually took place in 1909, and became the starting point of a movement resulting in the Chilean Pentecostal churches (Anderson 2015, 3).

18. The congregation led by Carl Magnus Seehuus (1864-1951) was originally Baptist. When news of the Welsh revival reached it, a revival including speaking in tongues arose in 1905. Seehuus and his congregation then became Pentecostal in 1908 (Bundy 2009, 317). It is counted as the first Pentecostal congregation in Norway. David Bundy describes the relationship between Barratt and Seehuus as competitive.

19. Originally the organization was named Norges Frie Evangeliske Missionsforbund, but the name was changed when an organization with a similar name, Det Norske Misjonsforbund, complained (Nilsen 1984, 39).

20. In 1919 "believers' baptism" (troendedåp) was introduced as a criterion for membership (Selbekk 2006, 157).

21. Barratt characterizes "Møllergaten 38" as the "mother congregation" of all the other Pentecostal assemblies in Norway (Barratt 2011, 213).

22. Oddvar Nilsen mentions that the total number of Pentecostal missionaries at this time was about 50 -in other words 20 missionaries were not associated with NFEH (Nilsen 1984, 67).

23. Aside from his pioneering work in the Congo and office as the first mission secretary (1946-1964), Gunnerius Tollefsen was a scholar and a prolific author. During his Congo period he published ethnographic studies and wrote the first Norwegian grammar of two local languages: Kiswaheli and Chinyabongo (Ski 1967b, 953-954). Gunnerius and his wife Oddbjørg Tollefsen adopted the Greek-Egyptian boy Emanuel Minos (1925-2014), who became a legendary preacher in Swedish and Norwegian Pentecostalism.

24. The English name is The Pentecostal Foreign Mission of Norway. Formerly, Pinsevennenes Ytre Misjon seems to have been the name in common use.

25. There are at present 293 congregations according to general secretary Bjørn Bjørnø (personal communication, January 10, 2015).

26. This was also communicated to me by general secretary Bjørn Bjørnø (February 10, 2015). 
27. Letter signed by general secretary Bjørn Bjørnø, February 12, 2015.

28. According to Oddvar Nilsen, Pentecostalism was brought to Iceland in 1920 by the Norwegian evangelist Erik Aasbø, who had also been present at the founding of the Pentecostal congregations in Göteborg and Örebro (Nilsen 1984, 55). David Bundy, however, referring to Petúr Petúrsson's Frain väckelse til samfund (1990), imparts a more complex account of the early history of Pentecostalism in Iceland (Bundy 2009, 224).

29. In Kobe, Kyoto, Nagoya, Seto, Fukui-Mikuni, Katsuyama, and Takefu (Nilsen 1984, 98).

30. A discourse analysis of the condemnation of Edvardsen by these leaders in the period 1965-1978 was undertaken by Terje Hegertun in Norsk tidsskrift for misjonsvitenskap (2009).

31. For several reasons more accurate figures are not given here. First, because there are a few names on the list for which I was unable to be certain of the gender. Second, a reservation (cf. Johansen et al. 2010, 108) indicates that probably there have been non-registered missionaries. Third, sheer numbers are no reliable indication of the scope and significance of the missionary work carried out by the two genders. Married men have had better opportunities to spend their time on work outside the household than married women. Also, the list says nothing about how long the individual has been in the field.

32. General secretary Bjørn Bjørnø (personal communication, February 10, 2015 ).

33. In Norwegian: "Din skaper er din ektemann." The sentence is a citation from Isaiah 54: 5 . In mission literature the deity often speaks in biblical phrasing (Mikaelsson 2010).

\section{REFERENCES}

Aalborg, Berit. 2014. Kristelige mannskulturer. Vårt Land, December 4.

Aarflot, Andreas. 1969. Tro og lydighet: Hans Nielsen Hauges kristendomsforstå lse. Oslo: Universitetsforlaget.

Alvarsson, Jan-Åke. 2011. The Development of Pentecostalism in Scandinavian Countries. In European Pentecostalism, ed. William K. Kay and Anne E. Dyer, 19-39. Leiden/Boston: Brill.

- 2015. En komparativ översikt av pentecostalismens historia i Norden från 1906 till i dag. In Pentekostale perspektiver, ed. Knut-Willy Sæther and Karl Inge Tangen, 31-16. Bergen: Fagbokforlaget.

Anderson, Allan. 2009. Pentecostalism in India and China in the Early Twentieth Century. In Global Pentecostalism: Encounters with Other Religious Traditions, ed. David Westerlund, 117-135. London/New York: I. B. Tauris.

2015. To All Points of the Compass: The Azusa Street Revival and Global Pentecostalism. Enrichment Journal, 1-13. http://enrichmentjournal.ag. org/200602/200602_164_allpoints.cfm. Accessed 31 Mar 2017. 
Arntsen, Ingrid Ofte. 2015. Høylydte feminister vs ydmyke kvinner? Vårt Land, January 8.

Barratt, T.B. 1933. Kvinnens stilling i menigheten. Korsets Seiers Forlag: Oslo.

Barratt, Thomas Ball. 1936. Ledetråd $i$ Guds ord: For ungdom og nyfrelste. Oslo: Filadelfiaforlaget.

—. 2011 [1941]. Erindringer. Oslo: Filadelfiaforlaget. Edition 2011 by Ronny Ranestad Larsen.

Bjøro, Terje. 2009. Robert Bergsaker til minne. Vart Land, October 5.

Bloch-Hoell, Nils. 1956. Pinsebevegelsen: En undersøkelse av pinsebevegelsens tilblivelse, utvikling og serpreg med serlig henblikk på bevegelsens utforming $i$ Norge. Oslo: Universitetsforlaget.

- 1964. The Pentecostal Movement: Its Origin, Development and Distinctive Character. Oslo/London: Universitetsforlaget/Allen \& Unwin.

Bundy, David. 2009. Visions of Apostolic Mission: Scandinavian Pentecostal Mission to 1935. PhD dissertation. University of Uppsala.

Danbolt, Erling. 1947. Misjonstankens gjennombrudd $i$ Norge, vol. 1, Misjonsappellens tid 1800-1830. Oslo: Egede-Instituttet.

Drønen, Tomas Sundnes, and Marianne Skjortnes, eds. 2010. Med hjertet på flere steder: Om barn, misjon og flerkulturell oppvekst. Trondheim: Tapir Akademisk Forlag.

Dyer, Anne E. 2011. Introduction. In European Pentecostalism, ed. William K. Kay and Anne E. Dyer, 1-15. Boston: Brill.

Engstrøm, Dagmar. 1980. Ha tro til Gud: Alt er mulig for den som tror. Oslo: Filadelfiaforlaget.

Fiedler, Klaus. 1994. The Story of Faith Missions. Oxford: Regnum Books International.

Froholt, Asbjørn. 1997. Landsmøtene i DFEF \& Misjonsutvalget - 50 år. Paper presented at the Annual Meeting of De Frie Evangeliske Forsamlinger (DFEF). www.dfef.no/artikkel/57/landsmøtene. Accessed 20 Apr 2017.

Gulbrandsen, Parley. 1937. Hedningemisjonen blandt pinsevennene. In Pinsevekkelsen $i$ Norge gjennem 30 ar 1907-1937, ed. J. Bratlie, 133-157. Oslo: Filadelfiaforlaget.

Gunnestad, Kirsti Thuseth. 2015. Kvinner i lederskap i Pinsebevegelsen i Norge: En undersøkelse av endringer i synet på kvinner i eldste- og forstandertjeneste i Pinsebevegelsen i Norge. In Pentekostale perspektiver, ed. Knut-Willy Sæther and Karl Inge Tangen, 203-220. Bergen: Fagbokforlaget.

Hegertun, Terje. 2009. Pinsestrid i økumenisk og diskursteoreetisk perspektiv. Norsk tidsskrift for misjonsvitenskap/Norwegian Journal of Missiology 3: 165-189.

Hoaas, Ole Georg, and Oddvar Tegnander. 1984. Kvinnen-fri til tjeneste? Oslo: Filadelfiaforlaget. 
Iversen, G. 1946. Blant indianere $i 35$ àr: Berger N. Johnsens misjonsarbeid $i$ Argentina. Sarpsborg: Johansen \& Larsen, Bok- og Aksidenstrykkeri.

Johansen, Oddvar, Kjell Hagen, Astrid Neema Nyen, and Paul Kolbjørnsrud. 2010. Pinsemisjon i 100 àr. Oslo: De norske pinsemenigheters ytremisjon.

Jones, Spencer. 1967. India. In Norsk Misjonsleksikon, ed. Fritjov Birkeli et al., vol. 2, 335-358. Stavanger: Nomi Forlag.

Jørgensen, Torstein, ed. 1992. I tro og tjeneste: Det Norske Misjonsselskap 1842-1992. Vol. 1. Stavanger: Misjonshøgskolen.

Kullerud, Dag. 1996. Hans Nielsen Hauge-mannen som vekket Norge. Oslo: Forlaget Forum; H. Aschehoug \& Co.

McGee, Gary B. 2010. Miracles, Missions, and American Pentecostalism. New York: Orbis Books.

Meyer, Ralph. 2015. Fra Kristiania til Kassel: Pinsebevegelsens begynnelse i Tyskland og forholdet til Gemeinschaftsbevegelsen. In Pentekostale perspektiver, ed. Knut-Willy Sxther and Karl Inge Tangen, 91-110. Bergen: Fagbokforlaget.

Mikaelsson, Lisbeth. 2003. Kallets ekko: Studier i misjon og selvbiografi. Stavanger: Høyskoleforlaget.

- 2005. The Heathen Woman in Norwegian Missionary Writing. In Gender, Poverty and Church Involvement: A Report from a Research Conference in Uppsala, May 6-8, 2002, Ed. Katharina Hallencreutz, 175-80. Missio no 20, Uppsala: Swedish Institute of Mission Research.

- 2010. Verification of the Word of God in Missionary Autobiography. In Canon and Canonicity: The Formation and Use of Scripture, ed. Einar Thomassen, 159-175. Copenhagen: Museum Tusculanum Press.

Molland, Einar. 1979. Norges kirkehistorie $i$ det 19. arhundre. Vol. 1. Oslo: Gyldendal Norsk Forlag.

Myklebust, Anders. 2014. Opprør mot mannsdominans. Vairt Land, December 19.

Nilsen, Oddvar. 1984. Ut $i$ all verden: Pinsevennenes ytre misjon $i 75$ år. Oslo: Filadelfiaforlaget.

Okkenhaug, Inger Marie, ed. 2003. Gender, Race and Religion: Nordic Missions 1860-1940. Uppsala: Studia Missionalia Svecana XCI.

Øverland, Per. 1987. Kortere avhandlinger om Brødremenigheten $i$ Norge. Trondheim: P. Øverland.

PYM. 2015. http://pymportal.com/about-us/(2015). Accessed 15 Jan 2015.

Rimehaug, Erling. 2010. Aril Edvardsen. Norsk biografisk leksikon. Last modified December 28, 2010. https://nbl.snl.no/Aril_Edvardsen. Accessed 27 Jan 2015.

Rudolph, Willy, and Spencer Jones. 1967. China. In Norsk Misjonsleksikon, ed. Fridtjov Birkeli et al., vol. 3, 480-486. Stavanger: Nomi Forlag. 
Seland, Bjørg. 2001. Religion på det frie marked. Folkelig pietisme og bedehuskultur. PhD dissertation. University of Bergen.

Selbekk, Vebjørn. 2006. T.B. Barratt forfulgt og etterfulgt. Skjetten: Hermon Forlag.

Simpson, Carl. 2011. The Development of Pentecostal and Charismatic Movements in the Germanic Countries. In European Pentecostalism, ed. William K. Kay and Anne E. Dyer, 61-83. Leiden/Boston: Brill.

Sjursen, Finn Wiig. 1993. Den hangianske periode: En bibliografi. Bergen: NLA-Forlaget.

- 1997. Den haugianske periode. Bergen: NLA-Forlaget.

Ski, Martin. 1967a. Pinsevennenes Ytre Misjon. In Norsk Misjonsleksikon, ed. Fritjov Birkeli et al., vol. 3, 450-470. Stavanger: Nomi Forlag.

_ 1967b. Tollefsen, Gunnerius. In Norsk Misjonsleksikon, ed. Fritjov Birkeli et al., vol. 3, 953-954. Stavanger: Nomi Forlag.

Slettan, Bjørn. 1992. “O, at jeg kunde min Jesum prise...”: Folkelig religiøsitet og vekkelsesliv på Agder på 1800-tallet. Oslo: Universitetsforlaget.

Solvoll, Berly Aarre. 1983. I mesterens haind: Med evangeliet til Østens folk. Oslo: Filadelfiaforlaget.

Sugirtharajah, Sharada. 2005. Ramabai, Pandita. In Encyclopedia of Religion, ed. Lindsay Jones, 2nd ed., 7610-7611. Detroit: Thomson Gale.

Tollefsen, Gunnerius. 1925. I Afrikas indre: Oplevelser og inntrykk fra en ekspedisjonsreise. Oslo: Eget forlag.

Tveit, Terje. 2011. Misjonær Liv Haug 40 år i Peru. Filadelfia Kristiansand, November 23. http://filadelfiakristiansand.ekanal.com/tekst/4070/MisjonerLiv-Haug-40-ar-i-Peru.aspx\#.WPiJbE1MTL8. Accessed 20 Apr 2017.

Open Access This chapter is distributed under the terms of the Creative Commons Attribution 4.0 International License (http://creativecommons.org/ licenses/by/4.0/), which permits use, duplication, adaptation, distribution and reproduction in any medium or format, as long as you give appropriate credit to the original author(s) and the source, provide a link to the Creative Commons license and indicate if changes were made.

The images or other third party material in this chapter are included in the chapter's Creative Commons license, unless indicated otherwise in a credit line to the material. If material is not included in the chapter's Creative Commons license and your intended use is not permitted by statutory regulation or exceeds the permitted use, you will need to obtain permission directly from the copyright holder.

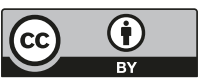

